Atmos. Chem. Phys., 13, 11339-11349, 2013

www.atmos-chem-phys.net/13/11339/2013/

doi:10.5194/acp-13-11339-2013

(c) Author(s) 2013. CC Attribution 3.0 License.

\title{
The Atmospheric Mercury Network: measurement and initial examination of an ongoing atmospheric mercury record across North America
}

\author{
D. A. Gay ${ }^{1}$, D. Schmeltz ${ }^{2}$, E. Prestbo ${ }^{3}$, M. Olson ${ }^{1}$, T. Sharac ${ }^{2}$, and R. Tordon ${ }^{4}$ \\ ${ }^{1}$ National Atmospheric Deposition Program, Illinois State Water Survey, 2204 Griffith Drive, Champaign, IL 61820, USA \\ ${ }^{2}$ US Environmental Protection Agency, Office of Atmospheric Programs, Clean Air Markets Division, 1200 Pennsylvania \\ Avenue, NW, MC6204J, Washington D.C. 20460, USA \\ ${ }^{3}$ Tekran Research and Development, 2707 NE 125th Street, Seattle, WA 98125, USA \\ ${ }^{4}$ Environment Canada, 45 Alderney Drive, Dartmouth, Nova Scotia, B2Y 2N6, Canada
}

Correspondence to: D. A. Gay (dgay@illinois.edu)

Received: 22 January 2013 - Published in Atmos. Chem. Phys. Discuss.: 19 April 2013

Revised: 22 September 2013 - Accepted: 4 October 2013 - Published: 22 November 2013

\begin{abstract}
The National Atmospheric Deposition Program (NADP) developed and operates a collaborative network of atmospheric-mercury-monitoring sites based in North America - the Atmospheric Mercury Network (AMNet). The justification for the network was growing interest and demand from many scientists and policy makers for a robust database of measurements to improve model development, assess policies and programs, and improve estimates of mercury dry deposition. Many different agencies and groups support the network, including federal, state, tribal, and international governments, academic institutions, and private companies. AMNet has added two high-elevation sites outside of continental North America in Hawaii and Taiwan because of new partnerships forged within NADP. Network sites measure concentrations of atmospheric mercury fractions using automated, continuous mercury speciation systems. The procedures that NADP developed for field operations, data management, and quality assurance ensure that the network makes scientifically valid and consistent measurements.

AMNet reports concentrations of hourly gaseous elemental mercury (GEM), two-hour gaseous oxidized mercury (GOM), and two-hour particulate-bound mercury less than 2.5 microns in size $\left(\mathrm{PBM}_{2.5}\right)$. As of January 2012, over 450000 valid observations are available from 30 stations. AMNet also collects ancillary meteorological data and information on land use and vegetation, when available. We present atmospheric mercury data comparisons by time ( $3 \mathrm{yr})$
\end{abstract}

at 21 individual sites and instruments. Highlighted are contrasting values for site locations across the network: urban versus rural, coastal versus high elevation and the range of maximum observations. The data presented should catalyze the formation of many scientific questions that may be answered through further in-depth analysis and modeling studies of the AMNet database. All data and methods are publically available through an online database on the NADP website (http://nadp.sws.uiuc.edu/amn/). Future network directions are to foster new network partnerships and continue to collect, quality assure, and post data, including dry deposition estimates, for each fraction.

\section{Introduction}

The current Mercury Deposition Network (MDN), initiated in the mid-1990s, provides data on the concentration of total mercury $(\mathrm{Hg})$ in precipitation at 110 sites across North America. MDN is one of five networks of the National Atmospheric Deposition Program (NADP), which monitors the rate of pollutant removal from the atmosphere and deposition loadings to ecosystems. MDN is a critical and valued component of a comprehensive Hg-monitoring strategy (Schmeltz et al., 2011). However, a lack of scientific information on the dry deposition of $\mathrm{Hg}$ and limited monitoring coverage over different geographic scales provides an incomplete picture 
of $\mathrm{Hg}$ atmospheric transport and total (wet + dry) $\mathrm{Hg}$ deposition. Based on atmospheric model estimates and several field studies, the dry deposition of $\mathrm{Hg}$ (particles and gases that deposit without the assistance of precipitation) has been estimated to be wide ranging relative to wet deposition. Earlier modeling found that dry deposition could be from much lower to much higher than wet deposition at different locations (Seigneur et al., 2004), while later modeling suggested that dry deposition in the US is greater than wet deposition (Selin et al., 2008) or equal in magnitude (L. Zhang, et al. 2012a). Several field-level studies also estimated dry deposition to be of the same magnitude as wet deposition (Lamborg et al., 2002; Caldwell et al., 2006; Lyman et al., 2007).

Three measurable atmospheric $\mathrm{Hg}$ fractions (i.e., individual chemical species and groups of the same) contribute to dry deposition: (1) gaseous elemental $\mathrm{Hg}$ (GEM), (2) gaseous oxidized $\mathrm{Hg}(\mathrm{GOM})$, and (3) particulate-bound $\mathrm{Hg}$ $\left(\mathrm{PBM}_{2.5}\right)$. The impact of $\mathrm{Hg}$ dry deposition on the total $\mathrm{Hg}$ deposition budget can be substantial. Even though estimated GEM dry deposition rates are small relative to GOM and $\mathrm{PBM}_{2.5}$, GEM comprises more than $95 \%$ of the total $\mathrm{Hg}$ in the air at ground level, and can be a significant component of dry deposition. GEM can be rapidly oxidized and deposited locally or regionally (Lindberg et al., 2002; Weiss-Penzias et al., 2003; Driscoll et al., 2007; Gustin et al., 2012), is important in forested ecosystem deposition (Grigal, 2002; Ericksen et al., 2003), and can be transported over long distances before deposition occurs. In situ oxidation of GEM to GOM/ $\mathrm{PBM}_{2.5}$ in the free troposphere has also been reported at high elevations in the US (Swartzendruber et al., 2006).

While scientists have quantified $\mathrm{Hg}$ in precipitation, the approaches to measuring dry deposition continue to evolve. Methods to measure dry deposition are actively under development (Lyman et al., 2009; Huang et al., 2011; Lai et al., 2011; Castro et al., 2012; Gustin et al., 2012; among others). When the NADP membership began considering an atmospheric Hg network in 2004, the most promising and available approach to estimate dry deposition in select locations was high-resolution, continuously measured concentrations of atmospheric $\mathrm{Hg}$ fractions, combined with modeled deposition parameters. At the time, network-scale atmospheric $\mathrm{Hg}$ data were not widely available, even though this need was recognized as important for improving the scientific understanding of the fate of atmospheric $\mathrm{Hg}$, including estimating Hg dry deposition (Fitzgerald, 1995; Mason et al., 2005; Harris et al., 2007).

Thus, starting in 2006, NADP advocates consulted a variety of $\mathrm{Hg}$ scientists to determine network viability and to explore standard methods to measure air $\mathrm{Hg}$ fractions in a network mode as a foundation for improving estimates of $\mathrm{Hg}$ dry deposition. In 2009, NADP formally launched the Atmospheric Mercury Network (AMNet) to measure atmospheric $\mathrm{Hg}$ concentrations needed to determine the dry deposition of $\mathrm{Hg}$ and also complement the $\mathrm{Hg}$ wet deposition measurements of MDN. Over 100 scientists contributed to the cur- rent instrument selection, development of equipment operating procedures, and data management methods adopted for use in AMNet. AMNet uses automated, continuous measuring systems to measure the atmospheric $\mathrm{Hg}$ fractions GEM, GOM, and $\mathrm{PBM}_{2.5}$. All network sites use standard operating procedures to operate and maintain the measuring equipment, including routine documentation. A single data management system processes all of the data with three levels of review in order to report consistent, quality-assured observations. We report here for the first time an accessible, standardized North American database of atmospheric $\mathrm{Hg}$ measurements that should provide for future trend analysis, model development, and total mercury deposition estimates. We also report on three years of observations from a number of monitoring locations and site groupings, compare and contrast the results, and identify several research questions as yet unanswered.

\subsection{Network objectives}

AMNet's goal is to coordinate, quality-assure, store, and share atmospheric concentration measurements of $\mathrm{Hg}$ fractions that contribute to dry and total $\mathrm{Hg}$ deposition. The network builds on NADP's $35 \mathrm{yr}$ history and experience of successful, collaborative environmental monitoring by offering a database of high-quality $\mathrm{Hg}$ measurements that complement the existing MDN program.

It is AMNet's objective to provide the database to multiple and diverse stakeholder groups to support an array of science, policy, and management objectives. As examples, the network has catalyzed new scientific investigations involving many different collaborators and sites, including regional-scale photochemical modeling (Baker and Bash, 2012), GOM dry deposition measurement (Castro et al., 2012), seasonal and diurnal variation of $\mathrm{Hg}$ fractions (Lan et al., 2012), a regional modeling assessment (L. Zhang, et al., 2012b), and an atmospheric $\mathrm{Hg}$ simulation over North America (Y. Zhang et al., 2012).

\section{Operation of AMNet}

\subsection{Monitoring locations}

To help categorize Hg cycling in different ecosystems, AMNet has a variety of siting classifications, including rural, urban, coastal, and high altitude locations. Many AMNet sites were previously established long-term air $\mathrm{Hg}$ research or monitoring sites. Current operating AMNet sites are described in Fig. 1 and Table 1. North American coverage is better throughout the east, but major gaps remain (central plains, southwest, Pacific Coast, much of the west, interior Canada, Rocky Mountains and high elevations, etc.). Several other sites operate in the west and south. Several urban sites operate in Birmingham, AL, New York City and Rochester, NY, and Salt Lake City, UT. High-elevation sites operate 
in Hawaii (3384 m) and in a new Asian location of Taiwan (2862 m.). A new site began operating in January 2012 in rural Wisconsin, but it is not considered here.

\subsection{Field operation}

Currently, all AMNet sites use the Tekran Continuous Mercury Vapor Analyzer Model 2537 coupled with the speciation models 1130 for GOM, and 1135 for PBM $_{2.5}$ (Tekran Instruments Corp., Toronto, Ontario, Canada). This equipment is not exclusive for use in the network, but it meets the AMNet requirements and is commonly available. The operation and principles of the instrument are described in Landis et al. (2002). Data captured using either personal computers or data loggers are submitted to the network monthly.

Standard operating procedures (SOPs) for AMNet were developed and reviewed by experts as described in network documentation. Full SOPs are available online (NADP, 2011a and b) and include sections on field operations, data management, site selection, and field maintenance and reporting procedures. Specific site information is available to data users, since location, terrain, land use, and other characteristics may have a significant influence on atmospheric $\mathrm{Hg}$ observations and deposition model application.

\subsection{Quality assurance and validation}

Prior to posting, the observed $\mathrm{Hg}$ data are quality-assured using a three-step process. Only valid data are made available six months after collection. Step one uses the NADP's automated quality assurance software to screen the raw data. This software evaluates the data, utilizing 35 potential flags (NADP, 2011a; Steffen et al., 2012). Twenty of the flags are warning limits established to initiate possible corrective actions in the field. Flags include zero and span deviations, bias between the dual GEM responses, low voltage response and drift, calibration intervals and significant changes between calibrations, presence of multiple response peaks, and sample volume variation over time, etc. If only warning flags are assigned, the data are considered valid. The remaining flags are control limits, which invalidate data when exceeded. Following automated QAP review, the data are set to a quality rating of " 1 ".

The AMNet site liaison performs step two by incorporating field observations, manually reviewing the data, and identifying any anomalies present through manual review of timeline graphics and statistical distributions. Data affected by maintenance are invalidated. At this point, the data are set to a quality rating of "2". The site liaison then provides site operators and investigators the opportunity for field verification by supplying them with a monthly report, including data anomalies.

The third step requires the site operator/investigator to approve the summarized data and initial data flags. Sites can clarify data records and have data reevaluated by the net- work. Once this process is completed, the data are set to a quality rating of " 3 ". Valid data with a quality rating of "3" are fully approved for reporting to the NADP website.

As an additional quality assurance step, the AMNet site liaison performs annual site audits, following specific audit criteria and testing procedures. These testing procedures include evaluation of siting criteria, instrument operation, and any additional training.

As mentioned, the AMNet data were generated using best available methods, procedures and quality assurance as determined by the consensus of the expert atmospheric mercury community. However, recent laboratory research studies have focused on determining GOM accuracy of field measurements. It is beyond the scope of this paper to address this complex research in depth, but it worth noting that a potential GOM measurement bias has been reported (Lyman et al., 2010; Gustin et al., 2013). Lyman et al. (2010) suggests that the oxidant ozone leads to a chemical reduction of collected GOM compounds on $\mathrm{KCl}$-coated annular denuders, releasing GEM from the denuder. The results suggest that although total $\mathrm{Hg}$ concentration would be unaffected, the GOM fraction could be biased low. A complex manifold-based GOM accuracy study acknowledged the challenges related to transport of $\mathrm{Hg}$ species, a hypothesized fast GOM formation reaction in the manifold, and a perplexing $30 \%$ bias in GEM concentrations as measured by the dual Tekran instruments (Gustin et al., 2013). Others have noted good agreement and no bias with co-located field-based $\mathrm{Hg}$ speciation analyzers (Prestbo et al., 2011). Thus, in our opinion the potential for bias in the measurement of GOM in the field, using standard methods, is still an issue requiring more study. As new knowledge and measurement techniques develop, AMNet will work collaboratively to improve the network.

\section{Data and availability}

\subsection{Measurements}

The Tekran 2537 continuously measures GEM for two hours in five-minute intervals. During this two-hour period of GEM measurements, GOM and $\mathrm{PBM}_{2.5}$ samples are being collected by denuder adsorption and filtering, respectively. The concentration of each fraction in ambient air is exceedingly low, hence the need for a high-flow, two-hour sample period. Following the two-hour sample period, the filter and denuder are heated, which converts the oxidized Hg in GOM and $\mathrm{PBM}_{2.5}$ to GEM. The GEM is released sequentially, into $\mathrm{Hg}$-free air flowing to the Tekran 2537 in order to determine the $\mathrm{Hg}$ concentration of $\mathrm{PBM}_{2.5}$ and GOM, respectively. The $\mathrm{PBM}_{2.5}$ and GOM analysis requires one hour. Thus, for every three-hour period, AMNet reports two GEM one-hour average values and the time-correlated two-hour $\mathrm{PBM}_{2.5}$ and GOM values. GEM concentrations are reported in nanograms per cubic meter $\left(\mathrm{ng} \mathrm{m}^{-3}\right)$, and GOM and 


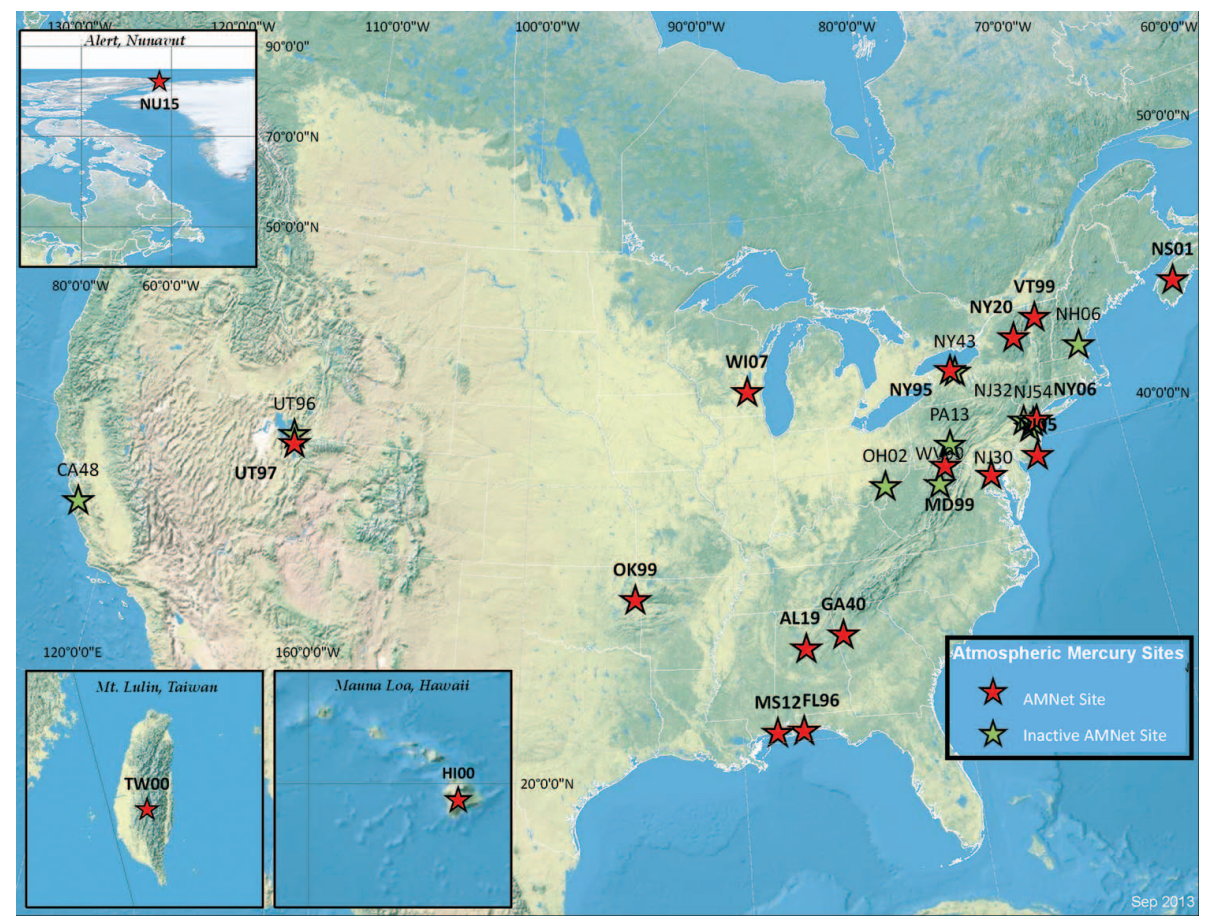

Fig. 1. Atmospheric Mercury Network sites, as of January 2012 (stars).

Table 1. Atmospheric Mercury Network site locations and general descriptions, as of January 2012.

\begin{tabular}{|c|c|c|c|c|c|c|c|c|c|c|}
\hline $\begin{array}{l}\text { NADP } \\
\text { Site ID }\end{array}$ & Site Name & Latitude & Longitude & Elev. (m) & Inlet Ht. (m) & Operating Agency & $\begin{array}{l}\text { Data } \\
\text { Availability } \\
\text { Start }\end{array}$ & $\begin{array}{l}\text { Data } \\
\text { Availability } \\
\text { End }\end{array}$ & $\begin{array}{l}\text { General Site } \\
\text { Condition }\end{array}$ & $\begin{array}{l}\text { Notes on Surrounding } \\
\text { Environment }\end{array}$ \\
\hline AL19 & Birmingham & 33.5530 & -86.8148 & 177 & 4.0 & ARA Inc. & $1 / 1 / 2009$ & ongoing & urban & urban \\
\hline CA48 & Elkhorn Slough & 36.8100 & -121.7800 & 10 & 3.1 & UC Santa Cruz & $1 / 1 / 2010$ & $12 / 31 / 2011$ & suburban & grass, lake \\
\hline FL96 & Pensacola & 30.5500 & -87.3753 & 44 & 5.0 & ARA Inc. & $1 / 1 / 2009$ & ongoing & rural & grass, open \\
\hline GA40 & Yorkville & 33.9283 & -85.0456 & 394 & 4.5 & ARA Inc. & $1 / 1 / 2009$ & ongoing & rural & grass, open \\
\hline HIOO & Mauna Loa & 19.5362 & -155.5761 & 3384 & 5.0 & NOAA & $1 / 1 / 2009$ & ongoing & rural & high elevation, open \\
\hline MD08 & Piney Reservoir & 39.7054 & -79.0126 & 761 & 3.1 & Un. of Maryland & $1 / 1 / 2009$ & ongoing & rural & Grass, mixed Forest \\
\hline MD96 & Beltsville_B & 39.0283 & -76.8171 & 47 & 10.0 & NOAA & $1 / 1 / 2009$ & ongoing & urban/suburban & Forest \\
\hline MD97 & Beltsville & 39.0283 & -76.8171 & 47 & 10.0 & NOAA & $1 / 1 / 2009$ & ongoing & urban/suburban & Forest \\
\hline MS12 & Grand Bay NERR & 30.4124 & -88.4038 & 1 & 10.0 & NOAA & $1 / 1 / 2009$ & ongoing & rural & woody, wetland, shrub, forest \\
\hline MS99 & Grand Bay NERR_B & 30.4124 & -88.4038 & 1 & 10.0 & NOAA & $1 / 1 / 2009$ & ongoing & rural & woody, wetland, shrub, forest \\
\hline NH06 & Thompson Farm & 43.1088 & -70.9485 & 25 & 4.3 & U New Hampshire & $1 / 1 / 2009$ & $11 / 29 / 2011$ & rural & mixed forest, crops \\
\hline NJ05 & Brigantine* & 39.4649 & -74.4488 & 8 & 4.0 & St. of New Jersey & $6 / 1 / 2009$ & ongoing & suburban & wetland, lake, forest \\
\hline NJ30 & New Brunswick* & 40.4728 & -74.4224 & 21 & 3.0 & St. of New Jersey & $1 / 1 / 2009$ & ongoing & urban & crop, forest \\
\hline NJ32 & Chester* & 40.7876 & -74.6764 & 276 & 1.0 & St. of New Jersey & $1 / 1 / 2009$ & ongoing & urban/suburban & forest, wetland \\
\hline NJ54 & Elizabeth Lab* & 40.6415 & -74.2085 & 5 & 3.0 & St. of New Jersey & $1 / 1 / 2009$ & ongoing & urban & urban \\
\hline NS01 & Kejimkujik & 44.4321 & -65.2031 & 158 & 5.0 & Environment Canada & $1 / 26 / 2009$ & ongoing & rural & forest \\
\hline NU15 & Alert* & 82.4509 & -62.5084 & 57 & 3.5 & Environment Canada & affiliated site & affiliated site & rural & Arctic \\
\hline NY06 & New York City & 40.8679 & -73.8782 & 26 & 9.1 & St. of New York & $1 / 1 / 2009$ & ongoing & urban & urban \\
\hline NY20 & Huntington Wildlife Forest & 43.9736 & -74.2232 & 502 & 4.9 & Clarkson U. & $1 / 1 / 2009$ & ongoing & rural & forest, lake, wetland \\
\hline NY43 & Rochester & 43.1544 & -77.6160 & 154 & 4.3 & Clarkson U. & $1 / 1 / 2009$ & $11 / 13 / 2009$ & suburban & urban \\
\hline NY95 & Rochester_B & 43.1463 & -77.5483 & 154 & 3.3 & St. of New York & $1 / 1 / 2009$ & ongoing & suburban & urban \\
\hline $\mathrm{OH} 02$ & Athens & 39.3080 & -82.1182 & 274 & 2.5 & Ohio Un. & $1 / 1 / 2009$ & $8 / 1 / 2012$ & rural & forest, shrubs \\
\hline OK99 & Stilwell & 35.7508 & -94.6696 & 300 & 4.0 & Cherokee Nation & $1 / 1 / 2009$ & ongoing & rural & grass, forest \\
\hline PA13 & Allegheny Portage & 40.4571 & -78.5603 & 739 & 3.6 & NOAA & $1 / 1 / 2009$ & ongoing & rural & grass, forest \\
\hline TW01 & Mt. Lulin, Taiwan & 23.5100 & 120.9200 & 2862 & 11.5 & Taiwan EPA & $1 / 1 / 2010$ & ongoing & rural & high elevation, open \\
\hline UT96 & Antelope Island & 41.0885 & -112.1187 & 1285 & 3.3 & Un. of Utah & $6 / 18 / 2009$ & $6 / 30 / 2011$ & suburban & grass, crops \\
\hline UT97 & Salt Lake City & 40.7118 & -111.9612 & 1099 & 8.2 & St. of Utah & $11 / 23 / 2008$ & ongoing & urban & urban \\
\hline VT99 & Underhill & 44.5285 & -72.8682 & 397 & 5.9 & Ecosystems Res. Gr. & $1 / 1 / 2009$ & ongoing & rural & grass, lake \\
\hline WI07 & Horicon & 43.4557 & -88.6169 & 272 & 4.0 & St. of Wisconsin & $1 / 1 / 2011$ & ongoing & rural & grass, lake \\
\hline WV99 & Canaan Valley Institute & 39.1189 & -79.4522 & 985 & 3.2 & NOAA & $1 / 1 / 2009$ & ongoing & rural & forest \\
\hline
\end{tabular}

* Affiliated Sites

$\mathrm{PBM}_{2.5}$ are reported in picograms per cubic meter $\left(\mathrm{pg} \mathrm{m}^{-3}\right)$. Each $\mathrm{Hg}$ value is reported with the AMNet site identifier, start time, end time, and additional quality assurance information. Observations are made at a standard temperature of $273 \mathrm{~K}$ and 1 atmosphere. All of the valid AMNet data are made available to the public through the NADP website (http://nadp.isws.illinois.edu). 


\subsection{Network intercomparison}

Environment Canada has a long history of network-based Hg-monitoring going back to 1996 with the start of the Canadian Atmospheric Mercury Measurement Network (CAMNet, Kellerhals et al., 2003; Temme et al., 2007). The Canadian network uses its own quality assurance software, the Research Data Management and Quality Assurance System $\left(\mathrm{RDMQ}^{\mathrm{TM}}\right)$, to quality assure and quality control data across CAMNet. In order to quantify the level of agreement between the two systems, raw data sets from multiple sites were processed through both software programs (Steffen et al., 2012). The final qualified data sets compared favorably between networks at the four tested sites, and the number of flags assigned by each program was generally very similar. For two of the longer-term, mid-latitude sites, results showed very good comparability. Mean differences in validated $\mathrm{Hg}$ fraction concentrations between the resulting data sets were small for GEM $(0.3 \%)$, and somewhat larger for GOM and $\mathrm{PBM}_{2.5}$ (8.6 and $15 \%$, respectively). However, for the high Arctic site, with extremely variable $\mathrm{Hg}$ values and difficult monitoring conditions, the quality-assured and validated data sets showed larger mean concentration differences $(2.7,27$, and $33 \%$, respectively). The robustness and general agreement between the two quality assurance programs provides confidence that $\mathrm{Hg}$ data generated by AMNet are quality-assured consistently with this network, although some differences were present.

\subsection{Network observations and analysis}

Statistics describing the currently available data and specific by-site statistics are in Supplement Table 1. As of January of 2012, there were approximately 150000 valid hourly and $2 \mathrm{~h}$ averages for each $\mathrm{Hg}$ fraction made by the network sites. Specific site-by-site observation number ranges from approximately 2500 to 11000 observations per site. Data for sites NJ30, NJ32, NJ54, NY43, NU15 (Alert), PA13, TW01 (Taiwan), WI07, and WV99 were not used for this overview.

With the abundance of data and sites available, we can make some basic observations of the quality assurance system results in network operation of the Tekran speciating system. For 5 min GEM observations, $80 \%$ of observations are valid with $10 \%$ excluded, leaving about $10 \%$ invalid observations for all years. For GOM and $\mathrm{PBM}_{2.5}, 86 \%$ of all observations for each are valid, with only $14 \%$ invalid. The most frequent reason for invalidation for all fractions is low instrument response $(5.2 \%, 6.5 \%$, and $6.3 \%$ respectively). For GEM, the second-most-frequent invalidation is for calibration bias (at $1.3 \%$ ). For GOM and $\mathrm{PBM}_{2.5}$ the secondmost-important invalidation is for cycles longer or shorter than normal ( $1.1 \%$ for each). These are typically power outages or maintenance where the instrument is idle for some reason.
The Mauna Loa, Hawaii high-elevation site has unique $\mathrm{Hg}$ observations compared to the other sites, so it is interpreted separately. The HIOO observations are similar to the other AMNet high-elevation site, Mt. Lulin, Taiwan (TW01, Sheu et al., 2010), and will be available in the future on the NADP website. Both high-elevation sites receive nighttime, subsiding free tropospheric air, which frequently has enhanced GOM and $\mathrm{PBM}_{2.5}$ and depleted GEM levels (Swartzendruber et al., 2006; Obrist et al., 2008; Fain et al., 2009; Lyman and Jaffe, 2011; Fig. 2a, b, c herewith). The HI00 site receives naturally emitted $\mathrm{Hg}$ from the active Kilauea Volcano (Nriagu and Becker, 2003). Even with a similar median GEM value, the interquartile range (2nd and 3rd quartiles) was the largest of any site at about $0.65 \mathrm{ng} \mathrm{m}^{-3}$, and the 5 th to 95th percentile range was $0.4 \mathrm{ng} \mathrm{m}^{-3}$ to $2.7 \mathrm{ng} \mathrm{m}^{-3}$ (Fig. 2a). Strikingly, the GOM and $\mathrm{PBM}_{2.5}$ median and mean values were five to ten times greater than any other site (Fig. $2 b$ and 2c). Further analysis of the HIOO and TW01 high-elevation sites is highly encouraged, but is beyond the scope of this work.

The AMNet GEM observations highlight several expected and unexpected results (Fig. 2a). For 15 of the 21 AMNet sites (excluding HI00), the median and mean GEM values were between 1.3 and $1.5 \mathrm{ng} \mathrm{m}^{-3}$, with a typical interquartile range of about $0.25 \mathrm{ng} \mathrm{m}^{-3}$. These values are similar to the range observed in contemporary measurements of total gaseous $\mathrm{Hg}$ and GEM measurements at long-term sites of Mace Head, Ireland (Ebinghaus et al., 2011; Slemr et al., 2011), multiple sites in the Canadian Atmospheric Mercury Measurement Network (CAMNet; Temme et al., 2007), and a relatively new rural Germany site (Weigelt et al., 2013). Three of 21 sites with means and medians well above this GEM range are urban or urban-influenced sites. Why does NY06, located in the heart of New York City, not match the other urban sites with higher GEM concentrations? With the largest single database of multi-year urban observations, AMNet provides a new opportunity to evaluate how urban areas influence mercury deposition. There is no clear reason why three of 21 sites have means and medians below $1.3 \mathrm{ng} \mathrm{m}^{-3}$. For example, consider NY20 and VT99; both are remote, continental forested sites in the northeastern USA approximately $100 \mathrm{~km}$ apart. NY20 and VT99 had contrasting GEM mean, interquartile, $95 \%$ and $\mathrm{min} / \mathrm{max}$ ranges. We postulate that site elevation and local effects may explain the differences. VT99 is located at a local high elevation and has a long fetch not influenced by surface exchange. NY20 is located in a lake valley and has a very short fetch to dense forest and therefore, in contrast to VT99, will experience air that is more influenced by mercury surface exchange. Therefore, these differences could be due to high-elevation exposure at VT99 to regional plume impacts but not with NY20 since it is situated in a more forested environment at lower altitude.

Most sites observed GEM below $2.0 \mathrm{ng} \mathrm{m}^{-3}$ for the overwhelming number of hours during all years. Minimum observations rarely went below $0.5 \mathrm{ng} \mathrm{m}^{-3}$. The 95 th percentile 
a)

AMNet Field Site (Years 2009-2011)

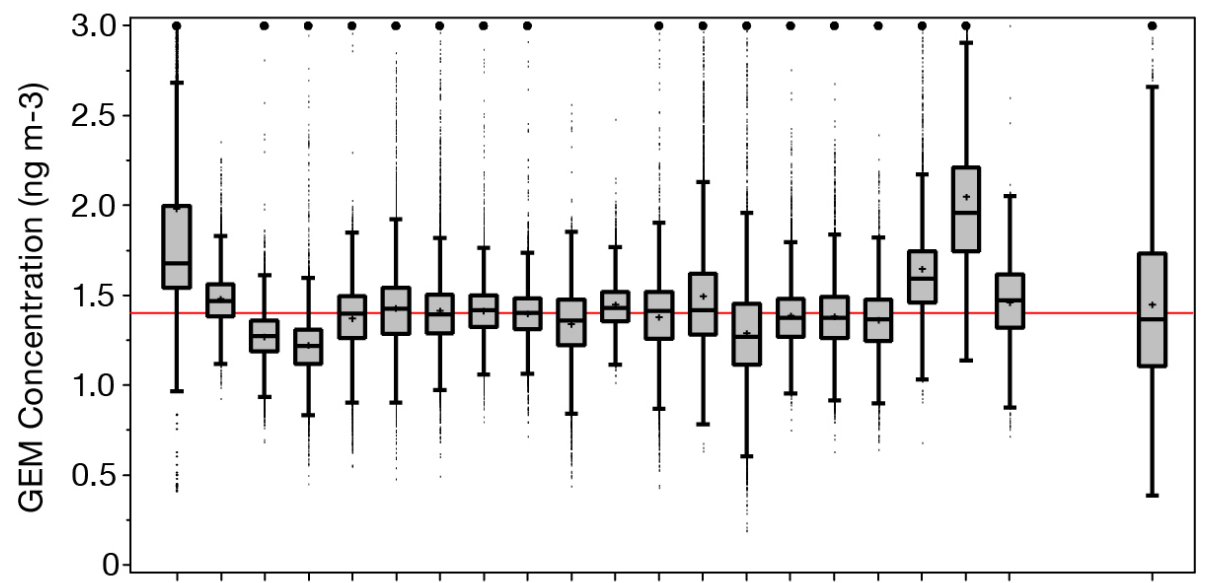

b)

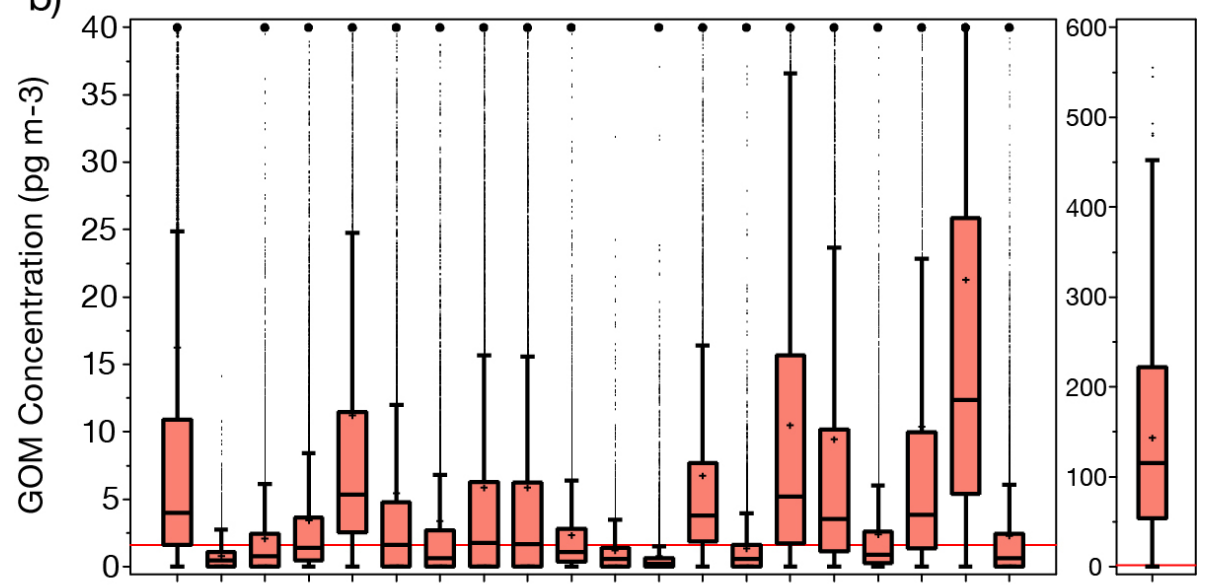

c)

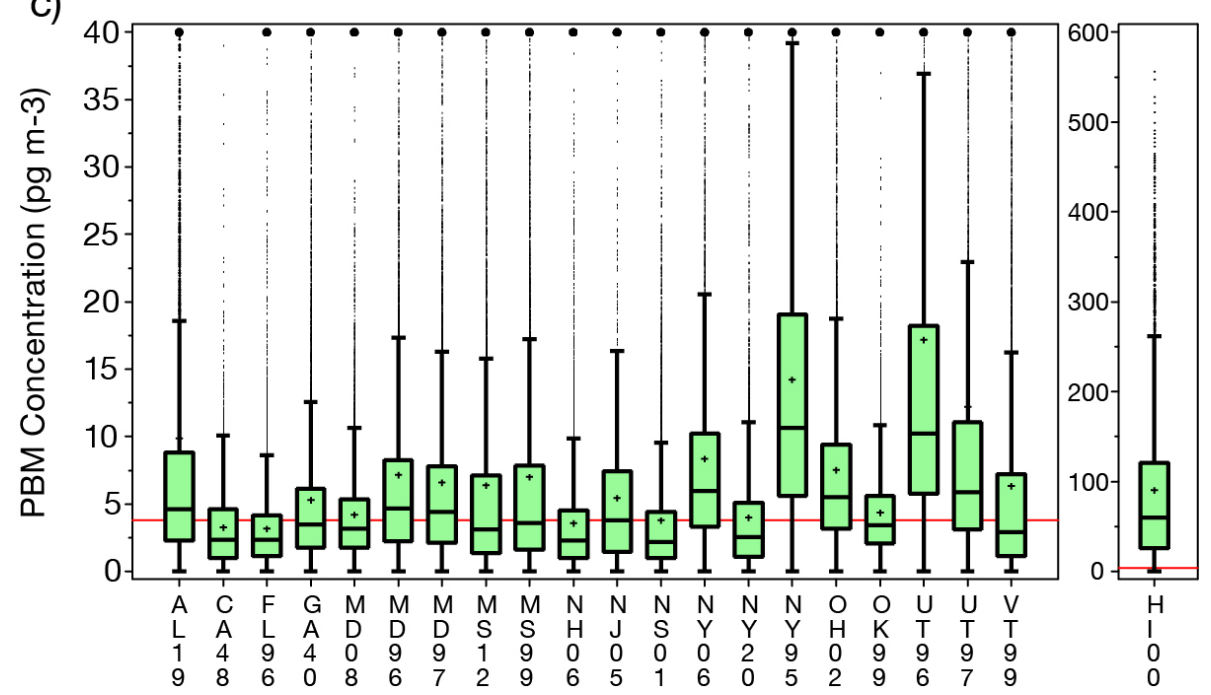

Fig. 2. Box-and-whisker plots of gaseous elemental mercury (GEM, $\mathrm{ng} \mathrm{m}^{-3}$, a) and for gaseous oxidized and particulate-bound mercury (GOM and $\mathrm{PBM}_{2.5}, \mathrm{pg} \mathrm{m}^{-3}, \mathbf{b}$ and $\mathbf{c}$ ) observations for all each site for years 2009 to 2011. Each box includes the median (midline), mean $(+), 25$ th and 75 th percentiles (box edges), 5th and 95th percentiles (whiskers), and individual values outside these limits (dots). Values above $3.0 \mathrm{ng} \mathrm{m}^{-3}$ and $40 \mathrm{pg} \mathrm{m}^{-3}$, respectively, are not shown (large dots). The respective medians of all observations are shown for reference (red lines, without HIO0 for GOM and $\mathrm{PBM}_{2.5}$ ). 
GEM concentrations for the sites were highly variable, ranging from 1.6 to $2.85 \mathrm{ng} \mathrm{m}^{-3}$. Year to year, the median change at these AMNet sites was small and limited to 0.1 or $0.2 \mathrm{ng} \mathrm{m}^{-3}$. Large numbers of extreme values are not limited to the sites with high GEM averages. Nearly all sites had multiple events above $3 \mathrm{ng} \mathrm{m}^{-3}$, with some sites with a great frequency of extreme values.

Ranges of GOM and $\mathrm{PBM}_{2.5}$ are shown in Fig. $2 \mathrm{~b}$ and c, respectively. The median GOM concentrations were typically between 1.2 and $2.5 \mathrm{pg} \mathrm{m}^{-3}$. The more remote sites were clearly the lowest, particularly for the marine Pacific and Nova Scotia sites. But the southern, coastal NJ05 site and the forested NY20 site were also very low. Perhaps at these sites, the combination of relative remoteness and coastal locations both led to lower values. At these sites, the GOM concentrations rarely exceeded $10 \mathrm{pg} \mathrm{m}^{-3}$. The highest medians were at two of the urban sites (Salt Lake City and Rochester, 5-12 $\mathrm{pg} \mathrm{m}^{-3}$ ). These two sites also had the largest interquartile range and 95th percentiles. However, a similar median and range was also measured in western Maryland (MD08). Conversely, New York City and Washington, D.C. were somewhat suppressed, relative to the other urban sites. Clearly, there are many factors at play in the resulting GOM values that may be better understood using source-receptor analysis or similar.

$\mathrm{PBM}_{2.5}$ medians were typically between 2.5 and $5.0 \mathrm{pg} \mathrm{m}^{-3}$. The highest two medians were measured at NY95 and UT96 $\left(10 \mathrm{pg} \mathrm{m}^{-3}\right.$, north of Salt Lake UT97), and the lowest at the coastal and continental remote sites $\left(\sim 2.5 \mathrm{pg} \mathrm{m}^{-3}\right)$. $\mathrm{PBM}_{2.5}$ was less than $15 \mathrm{pg} \mathrm{m}^{-3}$ for the majority of sites and observations. The interquartile ranges were usually between 2.0 and $7.5 \mathrm{pg} \mathrm{m}^{-3}$. The largest ranges were measured at NY95 and UT96, following with the highest medians. Both NY95 (Rochester, NY) and UT96 are within urban-influenced air sheds with active and historical industrial sources. Considering the very different environmental conditions, further analysis may show why these two different sites would both observe high particulate $\mathrm{Hg}$ concentrations.

In comparing the GOM values to $\mathrm{PBM}_{2.5}$ values (Fig. S1), we observed that all of the sites, save three, had median GOM concentrations less than $\mathrm{PBM}_{2.5}$. Therefore, most sites observed $\mathrm{PBM}_{2.5}$ levels greater than GOM, and more variable $\mathrm{PBM}_{2.5}$ values. The three sites that showed the opposite relationship of median GOM $>\mathrm{PBM}_{2.5}$ were the western Maryland MD08 site, HI00, and UT97 within Salt Lake City. Both UT96 and UT97 are unique AMNet sites because they are located in the high desert, very near the Great Salt Lake, within the urbanized metropolitan air shed and downwind of the greatest single concentration of gold mining mercury sources in the USA. The AMNet data set for UT96 and UT97 offers a unique opportunity for additional analysis, considering that the GOM and $\mathrm{PBM}_{2.5}$ ratios are quite different, even though the sites are approximately $44 \mathrm{~km}$ apart. Certainly the halide air chemistry will be important for UT96 and UT97, similar to observations made at the Dead Sea (Obrist et al., 2010). MD08 is in a different environment altogether from UT97, so it is predicted that the formation, source and dry deposition rate of $\mathrm{PBM}_{2.5}$ will be much different for these two locations.

It appears that site location relative to both natural and anthropogenic sources, elevation, and local conditions is influencing $\mathrm{Hg}$ concentrations. As an additional summary, we combined sites into loosely defined groups: the Pacific coast (CA48 only), coastal remote, continental remote, coastal near-sources, continental near-sources, urban and high elevation (HIO0 only). Definitive conclusions based on the analysis of the group results are not recommended, due to the limited number of sites per group and years of data. In effect, the group analysis should be used to direct deeper and more refined analysis.

The group with the highest GEM median, variability and maximum concentrations was the urban group (Fig. 3a). Interestingly, the continental remote group had the lowest median. Three groups, coastal remote, coastal near-sources and continental near-sources, had surprisingly similar medians and variability for GEM. The Pacific coast group is closer to urban GEM than it was to the coastal remote group, but with a narrow interquartile range. Some small point sources near CA48 could explain the higher GEM median; however, point sources usually result in more variability and some extreme values, which are not observed for CA48. A more likely explanation is GEM natural source emissions coming from the upwelling waters in Monterey Bay (Weiss-Penzias et al., 2013).

For GOM, the Pacific and coastal remote groups had the lowest median and variability (Fig. 3b). This is in contrast to some studies and models suggesting midday GOM production chemistry in the marine boundary layer (Laurier et al., 2003; Holmes et al., 2009). The median GOM for the continental near-sources group is high, and very similar to the urban group. Why does the continental near-sources group have a GEM median similar to other groups and the highest GOM median value? The coastal near-sources group has a lower median and range than the continental near-sources group. A coastal depletion in GOM relative to other groups is evident, at least from these observations. One would suspect this is due to enhanced precipitation removal and the lack of industrial sources in a seaward direction. This is distinct from GEM, where a coastal depletion relative to other groups is not present. But more work is clearly necessary given the limitations of our longer-term observations.

Similar to GOM, the highest $\mathrm{PBM}_{2.5}$ medians and interquartile ranges were observed for the continental nearsources and urban groups (Fig. 3b). The lowest median values and ranges were observed for the Pacific and coastal remote groups. The overall higher $\mathrm{PBM}_{2.5}$ to lower GOM relationship is clearly shown in all site groupings.

What may be more important, but is beyond the scope of this paper, is the magnitude and frequency of the GOM 

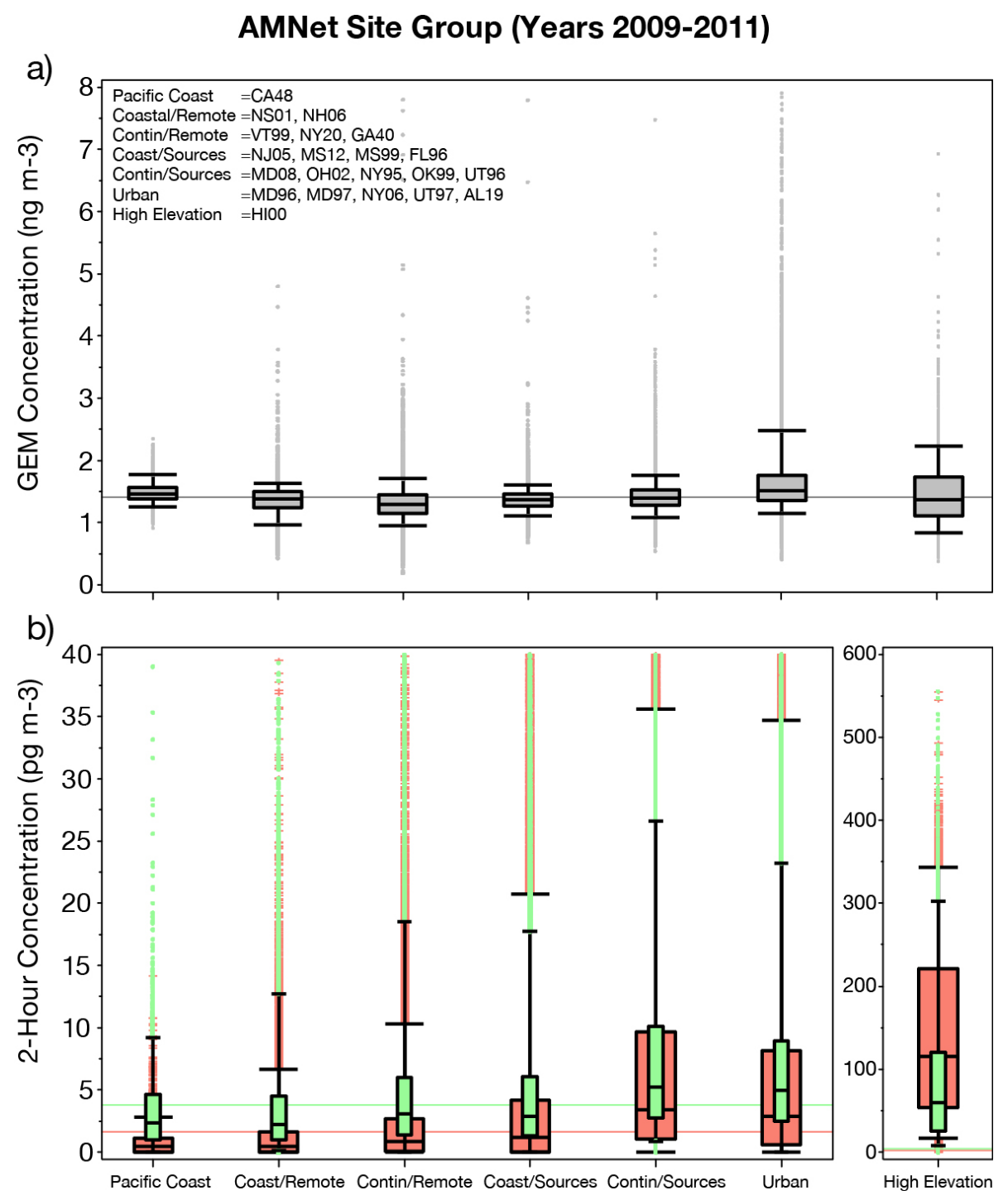

Fig. 3. Box-and-whisker plots of gaseous elemental mercury (GEM, ng $\mathrm{m}^{-3}$, a), and for gaseous oxidized and particulate-bound mercury (GOM in red, $\mathrm{PBM}_{2.5}$ in green, $\left.\mathrm{pg} \mathrm{m}^{-3}, \mathbf{b}\right)$ observations for site groupings for years 2009 to 2011 . Each box includes the median (midline), 25th and 75th percentiles (box edges), 5th and 95th percentiles (whiskers), and individual values outside these limits (dots/pluses). Values above $8.0 \mathrm{ng} \mathrm{m}^{-3}$ and $40 \mathrm{pg} \mathrm{m}^{-3}$, respectively, are not shown. The respective medians of all observations are shown for reference (silver, red and green lines, without HIO0 for GOM and $\mathrm{PBM}_{2.5}$ ).

and $\mathrm{PBM}_{2.5}$ values above the 75th and 95th percentile (Fig. 3b). Significant events are routinely reported for GOM and $\mathrm{PBM}_{2.5}$ at all the site groups, with the fewest for the Pacific coast and the most for the source, urban and highelevation (HIO0) groups. It will be informative to determine through future analysis how much the high GOM and $\mathrm{PBM}_{2.5}$ values impact the overall dry deposition rate at various sites.

\section{Importance, implications, and future directions}

The NADP has successfully developed and is operating an international-scale and long-term network of atmosphericHg-monitoring sites in North America, Hawaii, and Taiwan. Many different agencies and groups support the network, including federal, state, tribal, and international governments, academic institutions, and private companies. The collaborative efforts of many $\mathrm{Hg}$ experts and site personnel are critical for making consistent measurements using the same equipment and operation methods and a network-wide systematic review of data. 
The importance of AMNet is data, its availability, and its consistency over time and space. This consistency is a product of the standard operating procedures and quality assurance steps that AMNet puts in place. With long-term scientifically defensible data, it will be possible to expand our understanding of atmospheric mercury, with significant implications for science and policy decisions. Although the scope of the data analysis was purposely a high-level overview, the initial observations and questions raised in this work should catalyze additional in-depth data analysis. In the future, AMNet data will allow for

- the evaluation of, and improvements to, $\mathrm{Hg}$ air quality models, model intercomparison and development, and allow for model result comparisons;

- a baseline of atmospheric $\mathrm{Hg}$ concentrations to assess the magnitude of change due to regulation and expected emission reduction;

- determining the importance of atmospheric transport of local, regional and global sources to regional $\mathrm{Hg}$ concentrations and deposition; and

- stimulus and support of additional research and development into the biogeochemistry and cycling of mercury within ecosystems.

The network will continue to encourage new partners to join AMNet and improve the spatial coverage of the network over North America and other continents. Efforts are underway for the NADP, in collaboration with researchers at Environment Canada, to produce weekly dry deposition estimates from the $\mathrm{Hg}$ fractions measured at each operating site. Sites collocated with NADP/MDN will offer an estimate of total $\mathrm{Hg}$ deposition (wet + dry) to ecosystems.

This same focus on total $\mathrm{Hg}$ deposition has led to a trial network of litterfall deposition, used to estimate the litterfall input of $\mathrm{Hg}$ (NADP, 2012). Tied with AMNet and MDN, a more fully developed estimate of total deposition will be available at these select locations. Finally, the AMNet methods will be used to strengthen and facilitate consistency with other networks that measure $\mathrm{Hg}$ across the globe, including the European-led Global Mercury Observation System (GMOS, http://www.gmos.eu/), and potential future Hgmonitoring networks in Asia. The AMNet quality assurance program, including standard procedures for field operations, data review, and site audits, and the network intercomparison studies, are provided as a resource to the global monitoring community and an opportunity for further collaborations.

\section{Supplementary material related to this article is available online at http://www.atmos-chem-phys.net/13/ 11339/2013/acp-13-11339-2013-supplement.pdf.}

Acknowledgements. This network is able to function only with the work of the site operators, and Principal Investigators (M. Allen, St. of WI; S. Brooks, NOAA; R. Callison, Cherokee Nation; M. Castro, Un. of MD; K. Crist, Ohio Un.; E. Edgerton, ARA Inc.; D. Felton, St. of NY; T. Holson, Clarkson U.; W. Luke, NOAA; E. Miller, Ecosystems Res.; N. Olson, St. of UT; K. Perry, Un. UT; G.R. Sheu, National Central Un.; S. Steffen, Env. Canada; R. Talbot, Un. of NH; J. Dalziel, Env. Canada; P. Weiss, Un. CA Santa Cruz; and R. Zsolway, St. of NJ). Their effort and advice are very much appreciated.

This paper has not been subjected to US Environmental Protection Agency (EPA) peer and administrative review; therefore, the conclusions and opinions contained herein are solely those of the individual authors, and should not be construed to reflect the views of the EPA. A mention of trade names, products, or services does not convey, and should not be interpreted as conveying, official EPA approval, endorsement, or recommendation.

The NADP is National Research Support Project-3: A LongTerm Monitoring Program in Support of Research on the Effects of Atmospheric Chemical Deposition. More than 240 sponsors support the NADP, including State Agricultural Experiment Stations; universities; private companies and other nongovernmental organizations; Canadian government agencies; state, local, and tribal government organizations; and federal agencies, including the US Department of Agriculture - National Institute of Food and Agriculture (under agreement no. 2012-39138-20273). Any findings or conclusions in this article do not necessarily reflect the views of the Illinois State Water Survey, US Department of Agriculture, or other sponsors.

Edited by: R. Ebinghaus

\section{References}

Baker, K. R. and Bash, J. O.: Regional scale photochemical model evaluation of total mercury wet deposition and speciated ambient mercury, Atmos. Environ., 49, 151-162, 2012.

Caldwell, C. A., Swartzendruber, P., and Prestbo, E.: Concentration and dry deposition of mercury species in arid south central New Mexico (2001-2002), Environ. Sci. Technol., 40, 75357540, 2006.

Castro, M. S., Moore, C., Sherwell, J., and Brooks, S. B.: Dry deposition of gaseous oxidized mercury in Western Maryland, Sci. Total. Environ., 417, 232-240, 2012.

Driscoll, C. T., Han, Y. J., Chen, C. Y., Evers, D. C., Lambert, K. F., Holsen, T. M., Kamman, N. C., and Munson, R. K.: Mercury contamination in forest and freshwater ecosystems in the northeastern United States, Bioscience, 57, 17-28, 2007.

Ebinghaus, R., Jennings, S. G., Kock, H. H., Derwent, R. G., Manning, A. J., and Spain, T. G.: Decreasing trends in total gaseous mercury observations in baseline air at Mace Head, Ireland from 1996 to 2009, Atmos. Environ., 45, 3475-3480, 2011. 
Ericksen, J. A., Gustin, M. S., Schorran, D. E., Johnson, D. W., Lindberg, S. E., and Coleman, J. S.: Accumulation of atmospheric mercury in forest foliage, Atmos. Environ., 37, 1613$1622,2003$.

Faïn, X., Obrist, D., Hallar, A. G., Mccubbin, I., and Rahn, T.: High levels of reactive gaseous mercury observed at a high elevation research laboratory in the Rocky Mountains, Atmos. Chem. Phys., 9, 8049-8060, doi:10.5194/acp-9-8049-2009, 2009.

Fitzgerald, W. F.: Is mercury increasing in the atmosphere? Need for an Atmospheric Mercury Network (AMNet), Water Air Soil Poll., 80, 245-254, 1995.

Grigal, D. F.: Inputs and outputs of mercury from terrestrial watersheds: A review, Environ. Rev., 10, 1-39, 2002.

Gustin, M., Weiss-Penzias, P. S., and Peterson, C.: Investigating sources of gaseous oxidized mercury in dry deposition at three sites across Florida, USA, Atmos. Chem. Phys., 12, 9201-9219, doi:10.5194/acp-12-9201-2012, 2012.

Gustin, M. S., Huang, J., Miller, M. B., Peterson, C., Jaffe, D. A., Ambrose, J., Finley, B. D., Lyman, S. N., Call, K., Talbot, R., Feddersen, D., Mao, H., and Lindberg, S. E.: Do We Understand What the Mercury Speciation Instruments Are Actually Measuring? Results of RAMIX, Environ. Sci. Technol., 47, 7295-7306, doi:10.1021/es3039104, 2013.

Harris, R. C., Rudd, J. W., Amyot, M., Babiarz, C. L., Beaty, K. G., Blanchfield, P. J., Bodaly, R. A., Branfireun, B. A., Gilmour, C. C., Graydon, J. A., Heyes, A., Hintelmann, H., Hurley, J. P., Kelly, C. A., Krabbenhoft, D. P., Lindberg, S. E., Mason, R. P., Paterson, M. J., Podemski, C. L., Robinson, A., Sandilands, K. A., Southworth, G. R., St. Louis, V. L., and Tate, M. T.: Wholeecosystem study shows rapid fish-mercury response to changes in mercury deposition, P. Natl. Acad. Sci., USA, 104, 1658616591, 2007.

Holmes, C. D., Jacob, D. J., Mason, R. P., and Jaffe, D. A.: Sources and deposition of reactive gaseous mercury in the marine atmosphere, Atmos. Environ., 43, 2278-2285, 2009.

Huang, J., Liu, Y., and Holsen, T. M.: Comparison between knifeedge and frisbee-shaped surrogate surfaces for making dry deposition measurements: Wind tunnel experiments and computational fluid dynamics (CFD) modeling, Atmos. Environ., 45, 4213-4219, 2011.

Kellerhals, M., Beauchamp, S., Belzer, W., Blanchard, P., Froude, F., Harvey, B., McDonald, K., Pilote, M., Poisssant, L., Puckett, K., Schroeder, B., Steffen, A., and Tordon, R.: Temporal and spatial variability of total gaseous mercury in Canada: results from the Canadian Atmospheric Mercury Measurement Network (CAMNet), Atmos. Environ., 37, 1002-1011, 2003.

Lai, S. O., Huang, J., Hopke, P. K., and Holsen, T. M.: An evaluation of direct measurement techniques for mercury dry deposition, Sci. Total. Environ., 409, 1320-1327, 2011.

Lamborg, C. H., Fitzgerald, W. F., Damman, A. W. H., Benoit, J. M., Balcom, P. H., and Engstrom, D. R.: Modern and historic atmospheric mercury fluxes in both hemispheres: global and regional mercury cycling implications, Global Biogeochem. Cy., 16, 1104, doi:10.1029/2001GB001847, 2002.

Lan, X., Talbot, R., Castro, M., Perry, K., and Luke, W.: Seasonal and diurnal variations of atmospheric mercury across the US determined from AMNet monitoring data, Atmos. Chem. Phys., 12, 10569-10582, doi:10.5194/acp-12-10569-2012, 2012.
Landis, M. S., Stevens, R. K., Schaedlich, F., and Prestbo, E. M.: Development and characterization of an annular denuder methodology for the measurement of divalent inorganic reactive gaseous mercury in ambient air, Environ. Sci. Technol., 36, 3000-3009, 2002.

Laurier, F. J. G., Mason, R. P., Whalin, L., and Kato, S.: Reactive gaseous mercury formation in the North Pacific Ocean's marine boundary layer: A potential role of halogen chemistry, J. Geophys. Res., 108, 4529, doi:10.1029/2003JD003625, 2003.

Lindberg, S. E., Brooks, S. B., Lin, C.-J., Scott, K. J., Landis, M. S., Stevens, R. K., Goodsite, M., and Richter, A.: The dynamic oxidation of gaseous mercury in the Arctic atmosphere at polar sunrise, Environ. Sci. Technol., 36, 1245-1256, 2002.

Lyman, S. N., and Jaffe, D. A.: Formation and fate of oxidized mercury in the upper troposphere and lower stratosphere, Nature Geosci., 5, 114-117, 2011.

Lyman, S. N., Gustin, M. S., Prestbo, E. M., and Marsik, F. J.: Estimation of dry deposition of atmospheric mercury in Nevada by direct and indirect methods, Environ. Sci. Technol., 41, 19701976, 2007.

Lyman, S. N., Gustin, M. S., Prestbo, E. M., Kilner, P. I., Edgerton, E., and Hartsell, B.: Testing and application of surrogate surfaces for understanding potential gaseous oxidized mercury dry deposition, Environ. Sci. Technol., 43, 6235-6241, 2009.

Lyman, S. N., Jaffe, D. A., and Gustin, M. S.: Release of mercury halides from $\mathrm{KCl}$ denuders in the presence of ozone, Atmos. Chem. Phys., 10, 8197-8204, doi:10.5194/acp-10-81972010, 2010.

Mason, R. P., Abbott, M. L., Bodaly, R. A., Bullock, Jr., O. R., Driscoll, C. T., Evers, D., Lindberg, S. E., Murray, M., and Swain, E. B.: Monitoring the response to changing mercury deposition, Environ. Sci. Technol., 39, 14-22, doi:10.1021/es0531551, 2005 .

National Atmospheric Deposition Program (NADP): Atmospheric Mercury Network Data Management Manual (2011-12) Version 1.8., http://nadp.isws.illinois.edu/amn/docs/AMNet_Data_ Management_Manual.pdf, NADP Program Office, 2204 Griffith Dr., Champaign, IL 61820, 2011a.

National Atmospheric Deposition Program (NADP): Atmospheric Mercury Network Operations Manual (2011-05) Version 1.0., http://nadp.isws.illinois.edu/amn/docs/AMNet_Operations_ Manual.pdf, NADP Program Office, 2204 Griffith Dr., Champaign, IL 61820, $2011 \mathrm{~b}$.

National Atmospheric Deposition Program (NADP): NADP's Litterfall Mercury Monitoring Initiative, http://nadp.isws.illinois. edu/newIssues/litterfall/, accessed November, 2012, NADP Program Office, Illinois State Water Survey, 2204 Griffith Dr., Champaign, IL 61820, 2012.

Nriagu, J. and Becker, C.: Volcanic emissions of mercury to the atmosphere: global and regional inventories, Sci. Total. Environ. 304, 3-12, 2003.

Obrist, D., Hallar, A., McCubbin, I., Stephens, B. B., and Rahn, T.: Atmospheric mercury concentrations at Storm Peak Laboratory in the Rocky Mountains: Evidence for long-range transport from Asia, boundary layer contributions, and plant mercury uptake, Atmos. Environ., 42, 7579-7589, 2008.

Obrist, D., Tas, E., Peleg, M., Matveev, V., Faïn, X., Asaf, D., and Luria, M.: Bromine-induced oxidation of mercury in the midlatitude atmosphere, Nature. Geosci., 4, 22-26, 2010. 
Prestbo E. M., Gay D., Olson M., Luke W., Kelley P., Felton D., Holsen T., Huang J., and Choi H.-D.: An analysis of co-located atmospheric mercury speciation data from AMNet (2009-2010). International Conference of Mercury as a Global Pollutant, Nova Scotia, Canada, www.mercury2011.org, 2011.

Schmeltz, D., Evers, D. C., Driscoll, C. T., Artz, R., Cohen, M., Gay, D., Haeuber, R., Krabbenhoft, D. P., Mason, R., Morris, K., and Wiener, J. G.: MercNet: A national monitoring network to assess responses to changing mercury emissions in the United States, Ecotoxicology, 20, 1713-1725, 2011.

Seigneur, C., Vijayaraghavan, K., Lohman, K., Karamchandani, P., and Scott, C.: Global source attribution for mercury deposition in the United States, Environ. Sci. Technol., 38, 555-569, 2004.

Selin, N. E., Jacob, D. J., Yantosca, R. M., Strode, S., Jaeglé, L., and Sunderland, E. M.: Global 3-D land-ocean-atmosphere model for mercury: Present-day versus preindustrial cycles and anthropogenic enrichment factors for deposition, Global Biogeochem. Cy., 22, GB2011, doi:10.1029/2007GB003040, 2008.

Sheu, G. R., Lin, N. H., Wang, J. L., Lee, C. T., Ou Yang, C. F., and Wang, S. H.: Temporal distribution and potential sources of atmospheric mercury measured at a high-elevation background station in Taiwan, Atmos. Environ., 44, 2393-2400, 2010.

Slemr, F., Brunke, E.-G., Ebinghaus, R., and Kuss, J.: Worldwide trend of atmospheric mercury since 1995, Atmos. Chem. Phys., 11, 4779-4787, doi:10.5194/acp-11-4779-2011, 2011.

Steffen, A., Scherz, T., Olson, M., and Gay, D. A.: Atmospheric mercury measurement data: Quality control and assurance protocols for data standardization, J. Environ. Monitor., 14, 752-765, 2012.

Swartzendruber, P. C., Jaffe, D. A., Prestbo, E. M., Weiss-Penzias, P., Selin, N. E., Park, R., Jacob, D. J., Strode, S., and Jaeglé, L.: Observations of reactive gaseous mercury in the free troposphere at the Mount Bachelor Observatory, J. Geophys. Res., 111, D24301, doi:10.1029/2006JD007415, 2006.

Temme, C., Planchard, P., Steffen, A., Banic, C., Beauchamp, S., Poissant, L., Tordon, R., and Wiens, B.: Trend, seasonal and multivariate analysis study of total gaseous mercury data from the Canadian Atmospheric Mercury Measurement Network (CAMNet), Atmos. Environ., 41, 5423-5441, 2007.
Weigelt, A., Temme, C., Bieber, E., Schwerin, A., Schuetze, M., Ebinghaus, R., and Kock, H. H.: Measurements of atmospheric mercury species at a German rural background site from 2009 to 2011-methods and results, Env. Chem., 10, 102-110, 2013.

Weiss-Penzias, P., Jaffe, D. A., McClintick, A., Prestbo, E. M., Landis, M. S.: Gaseous elemental mercury in the marine boundary layer: Evidence for rapid removal in anthropogenic pollution, Environ. Sci. Technol., 37, 3755-3763, 2003.

Weiss-Penzias, P. S., Williams, E. J., Lerner, B. M., Bates, T. S., Gaston, C., Prather, K., Vlasenko, A., and Li, S. M.: Shipboard measurements of gaseous elemental mercury along the coast of Central and Southern California, J. Geophys. Res. Atmos., 118, 208-219, 2013.

Zhang, L., Blanchard, P., Gay, D. A., Prestbo, E. M., Risch, M. R., Johnson, D., Narayan, J., Zsolway, R., Holsen, T. M., Miller, E. K., Castro, M. S., Graydon, J. A., Louis, V. L. St., and Dalziel, J.: Estimation of speciated and total mercury dry deposition at monitoring locations in eastern and central North America, Atmos. Chem. Phys., 12, 4327-4340, doi:10.5194/acp-12-43272012, 2012a.

Zhang, L., Blanchard, P., Johnson, D., Dastoor, A., Ryzhkov, A., Lin, C. J., and Zhang, K. M.: Assessment of modeled mercury dry deposition over the Great Lakes region, Environ. Pollut., 161, 272-283, 2012b.

Zhang, Y., Jaeglé, L., van Donkelaar, A., Martin, R. V., Holmes, C. D., Amos, H. M., Wang, Q., Talbot, R., Artz, R., Brooks, S., Luke, W., Holsen, T. M., Felton, D., Miller, E. K., Perry, K. D., Schmeltz, D., Steffen, A., Tordon, R., Weiss-Penzias, P., and Zsolway, R.: Nested-grid simulation of mercury over North America, Atmos. Chem. Phys., 12, 6095-6111, doi:10.5194/acp12-6095-2012, 2012. 